\title{
Ethnobotany of MandailingTribe in Batang Gadis National Park
}

Aswarina Nasution ${ }^{1 *}$, Tatik Chikmawati ${ }^{1}$, Eko Baroto Walujo ${ }^{1}$, Ervizal Amir Muhammad Zuhud ${ }^{2}$

\footnotetext{
${ }^{1}$ Departement of Biology, Faculty of Mathematics and Natural Sciences, Bogor Agricultural University, Bogor, Indonesia

${ }^{2}$ Department of Forest Resources Conservation and Ecotourism, Bogor Agricultural University, Bogor, Indonesia
}

\section{ABSTRACT}

Batang Gadis National Park (BGNP) located in Bukit Barisan Mountains, Sumatera Utara. A Mandailing tribe who lives around the BGNP, has the unique local knowledge, such as processing young stem of rattan (Calamus manan) into pakkat (traditional food) and use rimbang (Solanum torvum) to neutralize toxins. These local knowledge could be lost because it only inherited orally from generation to generation. This study was aimed to reveal ethnobotany knowledge of Mandailing Tribe. The study was conducted in November 2015 in four villages around the BGNP, Sibanggor Jae, Hutabaringin Julu, Pastap Jae, and Botung Villages. Data were collected by interviewing informants in each village as well as the field survey through two approaches, emic and etic. A total of 262 plant species is used by Mandailing Tribe for subsistence and commercial needs. The highest utilization is for food (106 species), followed by traditional medicines ( 81 species), firewood (29 species), building materials (35 species), and animal feed (25 species). People also used plant for household appliances, agricultural equipment, art materials, ropes and wrap, and pest control materials. Eme/rice (Oryza sativa) have the highest Index of Cultural Significance (ICS) values. The existence of this species is maintained for its local wisdom. Thus, involvement of local community will give great contribution to manage and conserve the BGNP area.

Keywords: Utilization of forest resources, local knowledge, local wisdom

\section{INTRODUCTION}

Mandailing Tribe is an indigenous community who lives around the Batang Gadis National Park (BGNP) area. They have knowledge of the environmental unit and plant resources in its territory [1]. Its local knowledge is a result of people interaction with the forest ecosystem and biological resources for a long period, and it is influenced by the type of ecosystem in where they live, and the climate, especially rainfall, cultural, economic, technology and politics [2].

The BGNP is located in Bukit Barisan Mountains in North Sumatra. It is surrounded by 68 villages in 13 sub-districts [3]. There are about 240 identified plant species or approximately $0.9 \%$ of the plant species grows in Indonesia [4]. Biodiversity in the BGNP area could be decreased due to forest destruction in the North Sumatra Province. Data from the Ministry of Forestry has revealed the deforestation in the North Sumatera in

${ }^{*}$ Corresponding author:

Tatik Chikmawati

Departement of Biology, Faculty of Mathematics and Natural

Sciences, Bogor Agricultural University

Jalan Raya Dramaga, Bogor, Indonesia 16680

E-mail: tchikmawati@yahoo.com
2010 - 2012 was about 24,161.6 ha/year [5]. It indicates that the efforts to conserve and protect the biodiversity around BGNP need to be improved.

Local knowledge related to the plant resources are essential for the practice of conservation [6]. The involvement of local communities in the conservation of forest plants is very important stuff due to local communities have diverse relationships to the forest for long period, therefore they are more likely to appreciate the integrity of the whole forest ecosystem [7]. Several studies also conclude that there is a relation between local knowledge and the conservation efforts $[8,9]$.

Local knowledge is generally only inherited orally from generation to generation [10], so that the knowledge may be lost from a community. It is very dangerous for the preservation of the species since the rate of loss of species related to the traditional knowledge [11, 12]. So, it is important to document their local knowled-

\section{How to cite:}

Nasution A, Chikmawati T, Walujo EB, Zuhu EAM (2018)

Ethnobotany of MandailingTribe in Batang Gadis National Park. J. Trop. Life. Science 8 (1): $48-54$. 

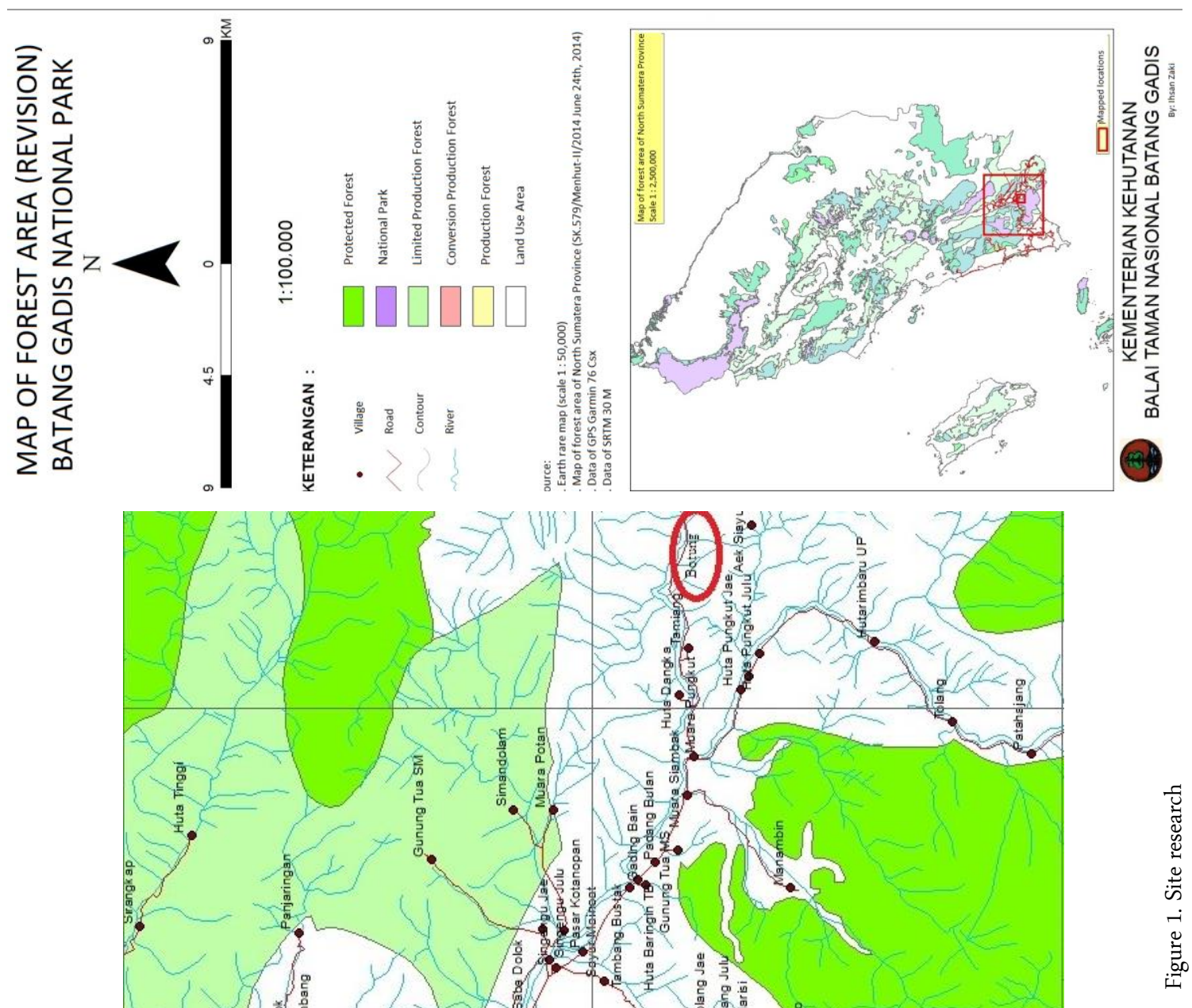
ge. This study aimed to reveal local knowledge of Mandailing Tribe about the plant resources through ethnobotanical perspective.

\section{MATERIALS AND METHODS}

Research was conducted in November 2015 in 4 villages: Sibanggor Jae, Hutabaringin Julu, Pastap Jae, and Botung Village (Figure 1). Ethnobotany data were collected by two approaches. Emic approach was done by exploring a holistic knowledge about the plant diversity through semi-structured interviews with the informants. Ethical approach was done by analyzing the Index of Importance Value (INP) in 4 landscapes. Analysis of vegetation in the forests, gardens and fields were used 5 plots, sized $20 \times 20 \mathrm{~m}$ of each plot. Analysis of vegetation in the yard was done by measuring the area outside the physical building. Ethical approach also conducted to analyze the Index of Cultural Significance (ICS) based on Turner [13] with some categories that had been modified by Purwanto [14].

Exploration survey was conducted by collecting specimens of plants used by local people for plant identification. Identification of plants was conducted in the Indonesian Institute of Sciences (LIPI), Cibinong. Standardization of botanical scientific name used a reference from the pages of the plant list. Data were analyzed by qualitative descriptive.

\section{RESULTS AND DISCUSSION}

\section{Ethnobotany knowledge of Mandailing Tribe}

People of Mandailing Tribe have a good knowledge about the plant diversity because they mostly work as farmers who actively interact with the plants. Their knowledge about plant includes identification, characterization and utilization of various plants in the forests, gardens, fields and settlements around them. They have some terms or local names to mention parts of a plant, such as: urat to mention a root, bulung to mention a leave, bungo to mention a flower and batuna to mention a seed. They also have a local knowledge about plant habitus such as duhut to mention seedlings (herbaceous) and hayu for shrubs and trees.

The plant diversity was used by the Mandailing Tribe consisted of 262 species belonged to 86 families. There are 28 families (33\%) of the total families ( $47 \mathrm{fam}$ ilies) were included in the plant inventory data of the Directorate of Forest Protection and Nature Conservation, Batang Gadis National Park in 2011. Mandailing Tribe used mostly plants for food (41\%), followed by medicine (31\%) (Figure 2).
The data showed that food and health are major priorities for their life, and it formed an independence of a village located near the forest [15].

\section{Food-producing plants}

Mandailing Tribe has known as many as 106 plant species for food. Eme/rice (Oryza sativa) is a staple food. Other foodstuffs are tubers ( 3 species), grain and nuts (7 species), vegetables (34 species), fruits (44 species), beverage ingredient ( 1 species), as well as seasoning (16 species).

Mandailing Tribe has been able to provide its own food using intercropping techniques, for example by planting long beans (Vigna unguiculata) interspersed with sabi/field mustard (Brasicca rapa). The technique provides benefits to their environment, including maintaining the diversity of plant species, avoiding transmission of plant diseases that widely occur in monoculture plantation, and providing habitat for soil microorganisms and profitable pollinators for the growth of crops, so it will increase the harvest productivity.

The ability of the community to meet its own subsistence is a form of local food security that needs to be maintained, and even enhanced to support the stability of the state food.

\section{Medicinal plants}

Mandailing Tribe used 81 species of medicinal plants to treat 41 diseases. Organs of plants used to treat various diseases are root, leaves, fruits, seeds, rhizomes, stem bark, fruit bark, fruit sap and stem sap. The most widely organ used by Mandailing Tribe were leaves (Figure 3).

This result is relevant to the result of previous study conducted by Irawan et al. [16]. The reason of using leaves for treatment is due to easily to obtain and processed it. The leaves also have a soft texture and contain various chemical compounds that have medicinal properties, for example, Senduduk/melastoma leaves (Melastoma malabathricum) is often used to treat wounds because it has anti-inflammatory and antioxidant activities [17]. Atirangga/garden balsam leaves (Impatiens balsamina) is used to treat malaria. Atirangga/ garden balsam leaves extracts containing benzene, chloroform, ethyl acetate and methanol have larvicidal properties against three vectors: Anopheles stephensi, Aedes aegypti, and Culex quinquefasciatus [18]. Artocarpus heterophyllus/jackfruit leaves has anti-malarial activity of Plasmodium falciparum and Plasmodium berghei [19]. Inggir-inggir/turkey berry leaves (Solanum torvum) is 


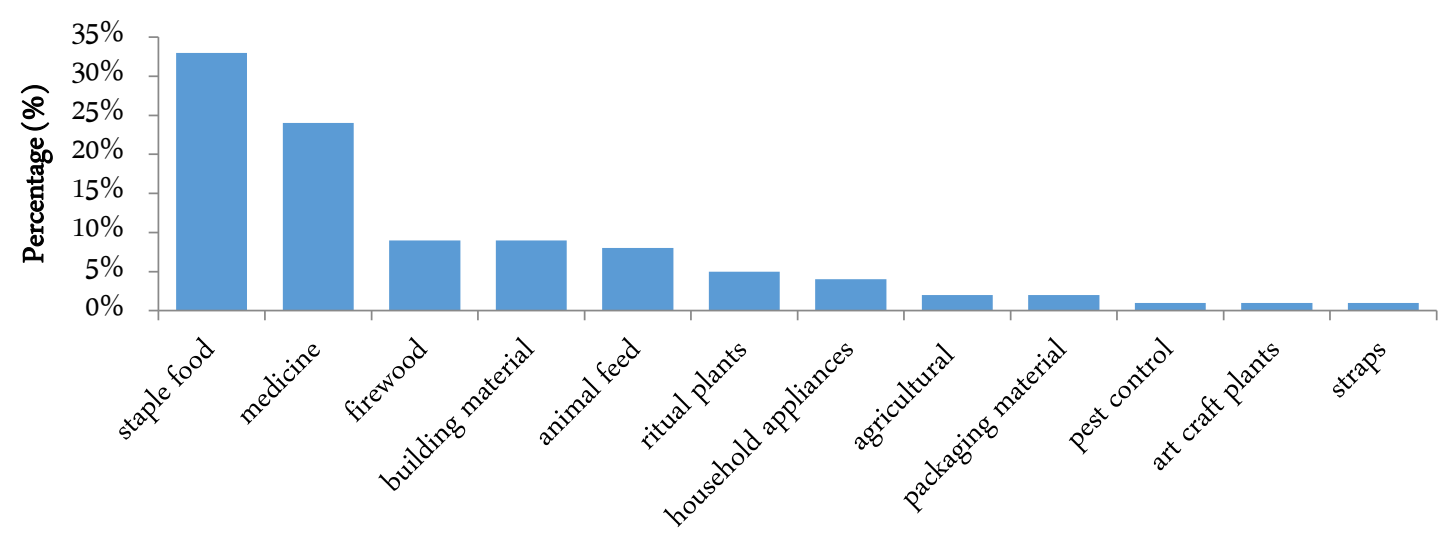

Utilization

Figure 2. The percentage of the number of plant species useful based from the utilization

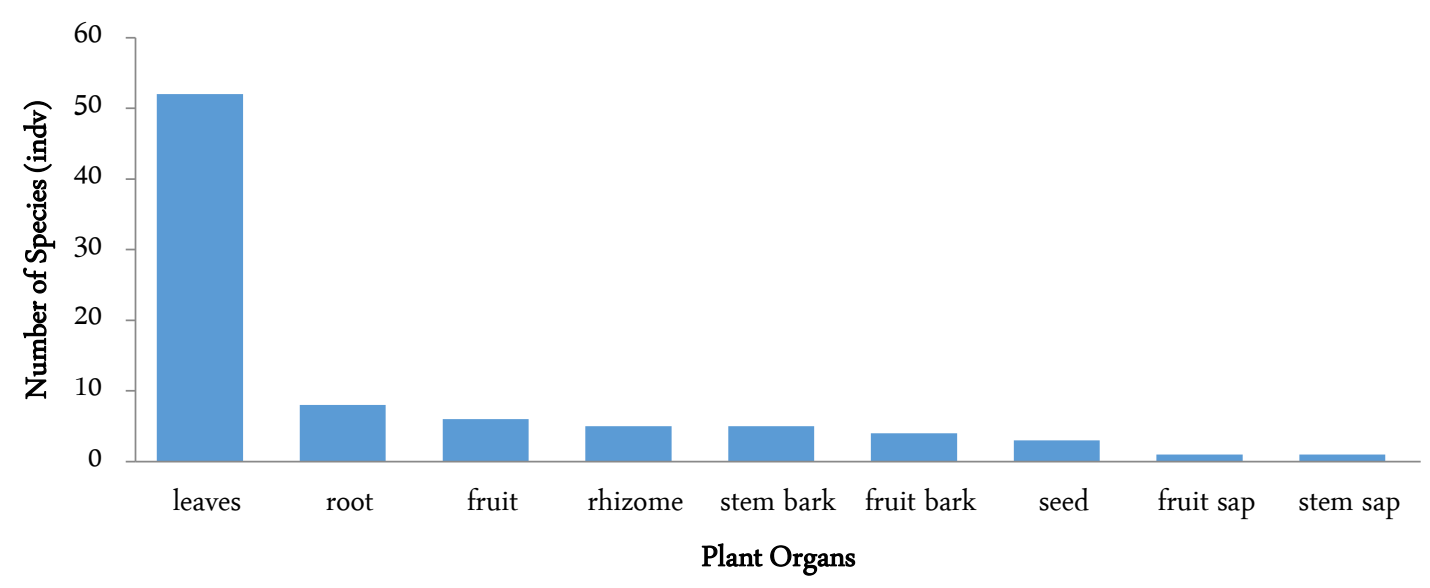

Figure 3. The number of plants species based organ in use

used for eye medications, poisoning and insect venom. Previous study reported that extract of inggir-inggir leaves could inhibit the growth of Staphylococcus aureus [20].

Mandailing Tribe used rhizome of nagorsing/turmeric (Curcuma domestica) to treat diarrhea. Rhizoma of Curcuma contains methanol that has an antidiarrheal activity [21]. The community knowledge about the medicinal plants may contribute to the development of modern medicine.

Plants for building material, firewood, household appliance, agricultural equipment, craft and art

Mandailing Tribe used 35 plant species for building material. Forests are a major source of building materials. The type of wood most widely used and preferred were ingul (Toona sureni) and tarutung/durian (Durio zibethinus).

Most people of Mandailing Tribe usually used firewood for cooking. They have specific criteria for fire- wood, i.e. produces a good quality flame, flammable, and easily cleaved. There were about 29 plant species that are used for firewood. Apea/rubber was able to absorb carbon dioxide quite high since it has wide canopy and has a wider leaf surface. Sibodak/jackfruit (A. heterophyllus) also has high ability to absorb carbon dioxide about $126.51 \mathrm{~kg} /$ year [22], so that the carbon content in the plant is high. Plant with higher carbon content will have better functions as for a fuel because it will produce larger thermal energy and long-lasting flame.

The Mandailing community was familiar with some household appliances from plastic or aluminum materials. But mostly, they still use traditional equipment from handicrafts or webbing for cookware or food container and other household appliances such as amparan (mat), bayan (a rice vessel) and balbahul (a flavoring vessel) made from garingging/screwpine (Pandanus tectorius). Losung (mortar), podoman (bed) and kukuran (grated coconut) made from ingul/suren toon (Toona sureni). People also used agricultural equipment made from 
plants, such as cakar, rambas (mowingtool) and pakkur (hoe) made from ingul/suren toon (T. sureni), sasabi (rice harvester) made from Cinamommum burmanii/ cinnamon and sarung lidang (a machete cover) made from garingging/screwpine ( $P$. tectorius). Art materials and craft such as gordang are made from harambir/coconut (Cocos nucifera) and Ingul/suren toon (T. sureni) and the hitter gordang made from coffee (Coffea sp.).

Mandailing community has applied several practical efforts to maintain forest sustainability. The people collecting wood from the forest only for their subsistence such as building houses or making furniture, but it is not used for commercial purposes. They also obtain the building material from their garden, so they maintain the existence of certain trees in the forest. They apply the agroforestry system in their gardens. A local wisdom called harangan rarangan is their last effort to minimize the impact of using forest trees as a building material. Harangan rarangan is a forest inhabited by spirits called naborgo-borgo who will endanger their life. With their belief, people are scared to enter and damage the area.

\section{Plants for animal feed, pest control, rope and wrapping}

Mandailing community used 25 plant species for animal feed. Most species were from the families of Malvaceae, Compositeae and Poaceae. Most Mandailing people used some plant species to control pest in their crops, including ubi oroson (Dioscorea hispida), bean (Phaseolus vulgaris), kacang jegang/jackbean (Canavalia ensiformis) and padang/cogon grass (Imperata cylindrica).

Alas/greater galangal (Alpinia galanga), andor bungo/black-eyed susan vine (Thunbergia alata) and bulung singkut/curculin (Curculigo latifolia) were widely used as a rope to tie up firewood in the forest so it is easy to be taken home. Many people used the leaves of herbs for wrapping foods such as alas/greater galangal (A. galanga), bulungsingkut/curculin (C. latifolia), coklat/chocolate (Theobroma cacao), garingging/ screwpine ( $P$. tectorius), nagorsing/turmeric (C. domestica) as well as leaves from various types of banana (Musa sp).

\section{Index of cultural significance of plant species for man- dailing tribe}

The analysis of cultural significance index of 262 useful plant species showed that ten plant species have higher ICS value in each village. Eme/rice (O. sativa) has the highest value of ICS among all the plants. Eme/rice has high utility value, and it was used more frequently and most preferred plant species by the com- munity. The usefulness of this species was as a staple food, animal feed, fertilizer and material for ritual.

Bargot/sugar palm (Arenga pinnata), kulit manis/ cinnamon (Cinnamommum burmanii), apea/rubber (Hevea brasiliensis), coffee (Coffea sp.), and harambir/coconut ( $C$. nucifera) were major commodities in Mandailing Tribe with high ICS value. Bargot/sugar palm (A. pinnata) in the Hutabaringin Julu has the highest ICS value (88) than that of Sibanggor Jae (72) and Pastap Jae (72). This plant has four benefits, as foodstuffs, building materials, medicine as well as for traditional craft materials. Brown sugar from bargot/sugar palm was a major commodity in the Hutabaringin Julu village.

ICS value indicate the importance of knowledge in plant utilization. A species that have high ICS value with a narrow distribution should be cultivated. In contrast, plants that are distributed in broad area, but have low ICS value, should look for other benefits [23].

The ICS and INP values of plant species were different in four villages so that the conservation strategies in every village should be different. Atunggal/ tiplant (Cordyline fruticosa) and hayu pelindung/quickstick (Gliricidia sepium) have high INP values (48.34 and 38.44 respectively) in the Sibanggor Jae village, but have lower ICS value (25 and 5 respectively). Salbi (Albizia lebbekoides) has high INP values (77.78 and 94.44) in the Pastap Jae Village, but have low ICS values (20 and 14). Thus, the community needs to increase the utilization of these species. Colocasia esculenta (suat) have low ICS (4.43) and INP values (28) in Hutabaringin Julu. $A$. galanga (alas) have low ICS (24) and low INP value (2.03) in Botung Village. It is necessary to increase the cultivation and utilization of this species.

Based on the result, it is concluded that forest is vital for the community in fulfilling their needs both in subsistence and commercial aspects. The local community effort to maintain the forest and plant resources surrounding them was applied in several ways, such as by implementation of a forbidden forest (harangan rarangan) and agroforestry systems.

Forbidden forests have a source of water and also a high diversity of flora and fauna, so it can be classified as a traditional conservation area. Community beliefs may change over time, and cultural intervention from outside the region. Thus, the community should be given the understanding that conserving nature is essential for the sustainability of natural resources, especially future crop resources.

Conservation based on local knowledge relating to 
a religion and the local community belief are generally more sustainable. Local community involvement in preserving forest is important because their local knowledge can be an input in the development of the BGNP area using sustainable principles.

\section{CONCLUSION}

There are 262 species belonged to 86 families used by Mandailing community. They could be classified as food ingredient (106 species), traditional medicines (81 species), building materials (35 species), firewood (29 species) and animal feed (25 species). People also used the plant for household appliances, agricultural equipment, art materials, ropes and wrapping, and pest control materials. The plants that have the highest value of ICS in four villages is eme/rice ( $O$. sativa) with a value of ICS 86-90. This species used as food, medicine, ritual and animal feed. The values of the plants in a community can be changed with the passage of time according to the change of the usability, intensity and the preference level of the community. Thus, in order to maintain plant sustainability, there must be a conservation effort for these plants.

\section{ACKNOWLEDGMENT}

This research was supported by Domestic Graduate Scholarship Program (BPPDN) of Directorate General of Higher Education, Ministry of Research, Technology and Higher Education.

\section{REFERENCES}

1. Lubis M, Dolok, Harisdani D, Devriza (1999) Mandailing: sejarah, adat dan arsitektur. Scientific Work. Universitas Sumatera Utara, Faculty of Engineering.

2. Walujo EB (2009) Etnobotani: Memfasilitasi penghayatan, pemutakhiran pengetahuan dan kearifan lokal dengan menggunakan prinsip-prinsip dasar ilmu pengetahuan. In Prosiding Seminar Nasional Etnobotani IV: May $18^{\text {th }}, 2009$; Cibinong. Edited by Purwanto Y, Walujo EB.

3. BKSDA II Sumatera Utara (2005) Rencana pengelolaan Taman Nasional Batang Gadis Kabupaten Madina Provinsi Sumatera Utara. Medan, Departemen Kehutanan.

4. Kartawinata K, Afriastini JJ, Heriyanto M, Samsoedin I (2004) A tree species inventory in a one-hectare plot at the Batang Gadis National Park, North Sumatera, Indonesia. Reindwardtia 12 (2): 145 - 157.

5. Kementerian Kehutanan (2013) Statistik kehutanan Indonesia 2012. Jakarta, Kementerian Kehutanan Republik Indonesia.
6. Rist L, Shaanker RU, Gulland EJM, Ghazoul J (2010) The use of traditional ecological knowledge in forest management: An example from India. Indian Ecology and Society 15 (1): 3 .

7. Barber CV, Johnson NC, Hafild E (1999) Menyelamatkan sisa hutan di Indonesia dan Amerika Serikat. Jakarta, Yayasan Obor Indonesia.

8. Siswadi, Taruna T, Purnaweni H (2011) Kearifan lokal dalam melestarikan mata air (Studi Kasus di Desa Purwogondo, Kecamatan Boja, Kabupaten Kendal). Jurnal Ilmu Lingkungan 9 (2): 63 - 68. doi: 10.14710/jil.9.2.63-68.

9. Oktavianti E, Hakim L (2013) Etnobotani pekarangan rumah inap (homestay) di Desa Wisata Tambaksari, Purwodadi, Pasuruan, Jawa Timur. Journal of Indonesian Tourism and Development Studies 1 (1): $39-45$.

10. Anderson EN, Pearsall DM, Hunn ES, Turner NJ (2011) Ethnobiology. New Jersey, Wiley and Sons Inc.

11. Sam HV, Bass P, Kebler, PJA (2008) Traditional medicine plant in Ben En National Park, Vietnam. Blumea - Biodiversity, Evolution and Biogeography of Plants 53 (3): 569 - 601. doi: 10.3767/000651908X607521.

12. Kartawinata K (2010) Dua abad mengungkap kekayaan flora dan ekosistem Indonesia. Jakarta, Bidang Lingkungan, Pusat Penelitian Biologi, Lembaga Ilmu Pengetahuan Indonesia (LIPI).

13. Turner NJ (1988) The importance of a rose: Evaluating the cultural significance of plants in Thompson and Lillooet interior salish. Journal of American Anthropologist 90 (2): 272 $-290$.

14. Purwanto Y (2005) Studi etnobotani Masyarakat Pekurehua di sekitar TN. Lore Lindu, Lembah Napu, Wuasa, Kecamatan Lore Utara, Kabupaten Poso, Sulawesi Tengah. Bogor, Laboratorium Etnobotani Pusat Penelitian Biologi - LIPI.

15. Zuhud EAM (2011) Pengembangan desa konservasi hutan keanekaragaman hayati untuk mendukung Kedaulatan Pangan dan Obat Keluarga (POGA) Indonesia dalam menghadapi ancaman krisis baru ekonomi dunia di era globalisasi. Bogor, Institut Pertanian Bogor.

16. Irawan YR, Fitmawati, Herman (2013) Pengetahuan tumbuhan obat dukun Sakai Desa Sebangar Duri Tiga Belas dan Desa Kesumbo Ampai Duri Kabupaten Bengkalis. Biosaintifika: Journal of Biology and Biology Education 5 (1): 30 - 35. doi: 10.15294/biosaintifika.v5i1.2571.

17. Nurdiana S, Marziana N (2013) Wound healing activities of Melastoma malabathricum leaves extract in Sprague dawley rats. International Journal of Pharmaceutical Sciences Review and Research 20 (2): $20-23$.

18. Govindarajan M, Rajeswary M (2014) Mosquito larvicidal properties of Impatiens balsamina (Balsaminaceae) against 
Anopheles stephensi, Aedes aegypti and Culex quinquefasciatus (Diptera: Culicidae). Journal of Coastal Life Medicine 2 (3): 222 - 224. doi: 10.12980/JCLM.2.2014JCLM-20140012.

19. Hafid AF, Septiani RP, Fabriana LH et al. (2016) Antimalarial activity of crude extracts of Artocarpus heterophyllus, Artocarpus altilis, and Artocarpus camansi. Asian Journal of Pharmaceutical and Clinical Research 9 (1): $279-281$.

20. Elmitra (2015) Uji daya hambat ekstrak etanol daun takokak (Solanum torvum Swartz) terhadap bakteri Stapylococcus aureus. Jurnal Ilmiah Pharmacy 2: $24-29$.
21. Chaithra D, Yasodamma N, Alekhya C (2015) Antidiarrhoeal activity of Curcuma neilgherrensis Wt. World Journal of Pharmacy and Pharmaceutical Sciences 4 (9): 545 - 555.

22. Endes D (2010) Trembesi dahulunya asing namun sekarang tidak lagi. Bogor, IPB Press.

23. Purwanto Y (2007) Hasil hutan Bukan Kayu (NTFPs): Terminologi dan Perannya Bagi Masyarakat di Sekitar Hutan. Bahan Kuliah Pasca Sarjana IPB. Bogor, Laboratorium Etnobotani Pusat Penelitian Biologi - LIPI. 